\title{
Bundle-branch block in the setting of acute anteroseptal myocardial infarction Clinicopathological correlation
}

\author{
ANTON E. BECKER, KONG I. LIE, AND ROBERT H. ANDERSON1 \\ From the Departments of Pathology and Cardiology, University of Amsterdam, Wilhelmina Gasthuis, \\ Amsterdam, The Netherlands
}

SUMMARY The anatomical substrate of bundle-branch block in the setting of acute anteroseptal infarction is as yet controversial. Some investigators have reported massive bundle-branch necrosis, while others have indicated that necrosis does not play a major role. The present study has correlated electrocardiographic data with histopathological findings of the atrioventricular conducting tissues in 37 hearts with an acute anteroseptal infarction. There were 22 patients who developed some sort of bundle-branch block, whereas 15 patients died of their infarction without developing block.

The results showed that the atrioventricular node and penetrating (His) bundle were never involved in either group, while in both groups the ischaemic process frequently involved the distal ramifications of right and left bundle-branches, sometimes with the production of the necrosis of bundle-branch cells. The difference between groups was found in the proximal bundle-branches. The hearts without bundlebranch block did show an occasional pathological change in these parts of the conducting tissues, whereas nearly all the hearts of patients who developed block showed ischaemia, hydropic cell swelling being the dominant feature.Necrosis was a rare phenomenon at these sites.It is suggested that the changes observed in the proximal bundle-branches are responsible for the conduction disturbances. Since hydropic cell swelling does not necessarily lead to cell death, restoration of conduction could have been expected in the majority of cases had they survived the initial infarction. Thus, our results support the concept that the prognosis of acute anteroseptal infarction relates primarily to the extent of infarction.

Bundle-branch block has grave prognostic significance when it develops in the course of acute myocardial infarction. Thus, Lie et al. (1974) observed a hospital mortality of 74 per cent among such patients. They related mortality to the extent of the infarction itself rather than to involvement of the conducting system, since in some patients bundle-branch block was transient in nature. Furthermore, others had reported that temporary pacing did not affect immediate prognosis in patients who developed complete atrioventricular block during acute infarction (Norris et al., 1972). These facts raise the question of the degree of involvement of the conducting tissues in the ischaemic process. It is perhaps surprising, therefore, that in sharp contradistinction to the many publications on

${ }^{1}$ RHA was a Medical Research Council Travelling Fellow, United Kingdom, during the course of this investigation. He is now a British Heart Foundation Senior Research Fellow, Brompton Hospital, London, England.

Received for publication 9 June 1977 chronic bundle-branch block reviewed in detail by Davies (1971), relatively few investigators have studied the histopathology of the conducting system in acute infarction (Blondeau et al., 1961; Lev et al., 1961; Blondeau et al., 1967; Sutton and Davies, 1968; Hackel and Estes, 1971; Hackel et al., 1972; Hunt et al., 1973). All who have studied the problem agree that, in case of anteroseptal infarction, pathological involvement of bundle-branches is dependent on the extent of the infarction of the ventricular septum. However, investigators disagree about the degree and nature of bundle-branch involvement. Some have found massive bundlebranch necrosis to be the underlying pathological process (Sutton and Davies, 1968; Hunt et al., 1973). Others have found that bundle-branch necrosis is not always present, and that when present it may occur to a variable extent (Blondeau et al., 1961; Blondeau et al., 1967; Hackel and Estes, 1971; Hackel et al., 1972).

In view of these diverging opinions we have examined the hearts from 22 patients who developed 
bundle-branch block during acute anteroseptal infarction, and compared them with 15 hearts from patients suffering such infarction in the absence of electrocardiographic evidence of bundle-branch block.

\section{Subjects and methods}

Thirty-seven patients who died during the course of acute anteroseptal infarction were studied. Relevant data including the time intervals between onset of myocardial infarction, onset of bundle-branch block, and death are shown in Table 1 . In 22 of these patients, electrocardiographic monitoring showed the development of bundle-branch block during the clinical course. The remaining 15 patients had no electrocardiographic evidence of bundle-branch block.

Table 1 Time relations between onset of myocardial infarction and development of bundle-branch block, onset of bundle-branch block, and death in relation to type of block as judged from electrocardiogram

\begin{tabular}{llll}
$\begin{array}{l}\text { Case } \\
\text { No. }\end{array}$ & $\begin{array}{l}\text { Onset of infarction } \\
\text { to development of } \\
\text { bundle-branch block }\end{array}$ & $\begin{array}{l}\text { Onset of bundle- } \\
\text { branch block to } \\
\text { death }\end{array}$ & $\begin{array}{l}\text { Type of bundle- } \\
\text { branch block }\end{array}$ \\
\hline 1 & 3 days & 1 day & RBBB \\
2 & 5 hours & 18 hours & RBBB \\
3 & 3 hours & 12 hours & RBBB \\
4 & 7 hours & 24 hours & RBBB \\
5 & 4 hours & 20 hours & RBBB \\
6 & 15 hours & 3 days & RBBB \\
7 & 3 hours & 10 days & RBBB \\
8 & 2 hours & 3 weeks & RBBB \\
9 & 6 hours & 2 days & RBBB \\
10 & 4 hours & 6 hours & RBBB + LPH \\
11 & 4 hours & 6 hours & RBBB + LPH \\
12 & 4 hours & 8 hours & RBBB + LPH \\
13 & 20 hours & 24 hours & RBBB + LPH \\
14 & 2 days & 7 days & RBBB + LAH \\
15 & 3 hours & 22 hours & RBBB + LAH \\
16 & 14 hours & 2 days & CHB \\
17 & 16 hours & 17 days & CHB \\
18 & 2 days & 8 days & CHB \\
19 & 6 hours & 18 hours & CHB \\
20 & 1 day & 5 weeks & CHB \\
21 & 13 hours & 2 days & CHB \\
22 & 5 hours & 8 days & CHB \\
\hline & & & \\
\hline
\end{tabular}

Abbreviations: CHB, complete heart block; LAH, left anterior hemiblock; LPH, left posterior hemiblock; RBBB, right bundlebranch block.

In each instance a complete necropsy was performed, including a postmortem coronary angiogram. Thereafter the coronary arterial system was grossly sectioned at $3 \mathrm{~mm}$ intervals. The extent of myocardial infarction was ascertained by gross observation and microscopical studies. The atrioventricular conduction system was then studied without prior knowledge of the electrocardiographic findings. This was performed by removing blocks of

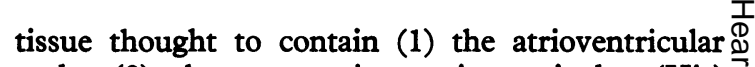
node, (2) the penetrating atrioventricular (His) bundle, (3) the intramyocardial segment of the right $\Rightarrow$ bundle-branch, (4) the proximal part (main stem) $\stackrel{9}{9}$ of the left bundle-branch, (5) the distal part of the 0 right bundle-branch in its course through the $\bar{\equiv}$ moderator band, and (6) and (7) anterior and $\frac{\bar{c}}{\frac{5}{5}}$ posterior radiations of the left bundle-branch, $\mathbb{\otimes}$ respectively (Fig. 1).

Initially, single sections were cut from each block ${ }^{\infty}$ and stained with haematoxylin and eosin, and with. an elastic tissue stain counterstained with van $\vec{\omega}$ Gieson's stain. However, the blocks containing the $\stackrel{\omega}{\circ}$ proximal bundle-branches were always serially sectioned when they showed infarcted myocardium. Moreover, in all instances where block 3 (for the study of the intramyocardial course of the right $y$ bundle-branch) contained infarcted myocardium, $\omega$ adjacent blocks were taken in order to determine the 을 precise relation between the bundle-branch and the infarction. If findings were still unequivocal, blocks were taken from appropriate sites.

\section{Results}

(A) NORMAL HISTOLOGY OF ATRIOVENTRICULAR NODE, HIS BUNDLE, AND BUNDLE-BRANCHES

The atrioventricular node is composed of small $\frac{2}{D}$ muscle cells, definitely smaller than working atrial $\underset{\vec{P}}{\overrightarrow{2}}$ myocardial cells, and are loosely arranged in an interweaving fashion. This type of fibre continues into the penetrating atrioventricular (His) bundle and the distinction between node and bundle is best made arbitrarily at the site where the nodal- $\widehat{D}$ bundle axis becomes separated from atrial myocardium by fibrous tissue (Becker and Anderson, $\frac{\dot{\sigma}}{3}$ 1976). In the penetrating bundle, the fibres gradually assume a parallel arrangement, their size also increasing. This increase in fibre diameter continues in the bifurcating bundle, and into the main stem $\frac{\text { o }}{9}$ of the left bundle-branch. By this time the con- $D$ ducting fibres have become larger than working myocardial fibres (Fig. 2A). As the main left bundle $\tilde{N}$ passes distally, the fibres fan into the anterior, septal, and posterior radiations, the diameters of the $O$ constituent cells being similar to those of the main $\mathrm{\omega}$ left bundle (Fig. 2B and C). In our experience it is rare to find vacuolated or large, pale cells in the 0 normal left bundle-branch. The right bundle- $\mathbb{D}$ branch retains the fibre characteristics of the pene- $\stackrel{\mathscr{N}}{+}$ trating atrioventricular bundle for the greater part $\frac{7}{0}$ of its intramyocardial course, the constituent cells $\stackrel{\vec{D}}{\vec{D}}$ being similar in size to those of the working myo- $\frac{\rho}{\Phi}$ cardium (Fig. 2D). As the bundle ramifies in the $\stackrel{\unrhd}{\perp}$ subendocardium of the ventricular apex, the cells 


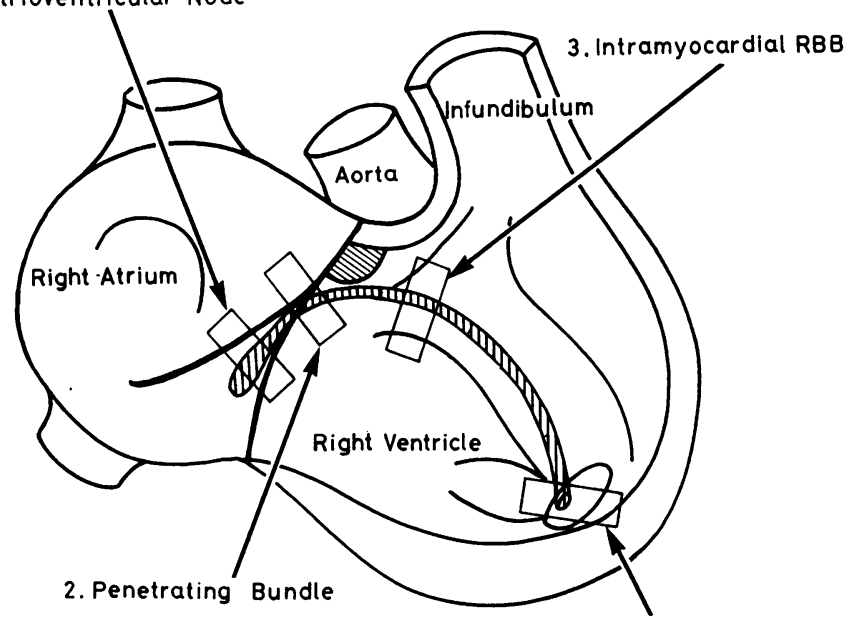

5. Moderator Band

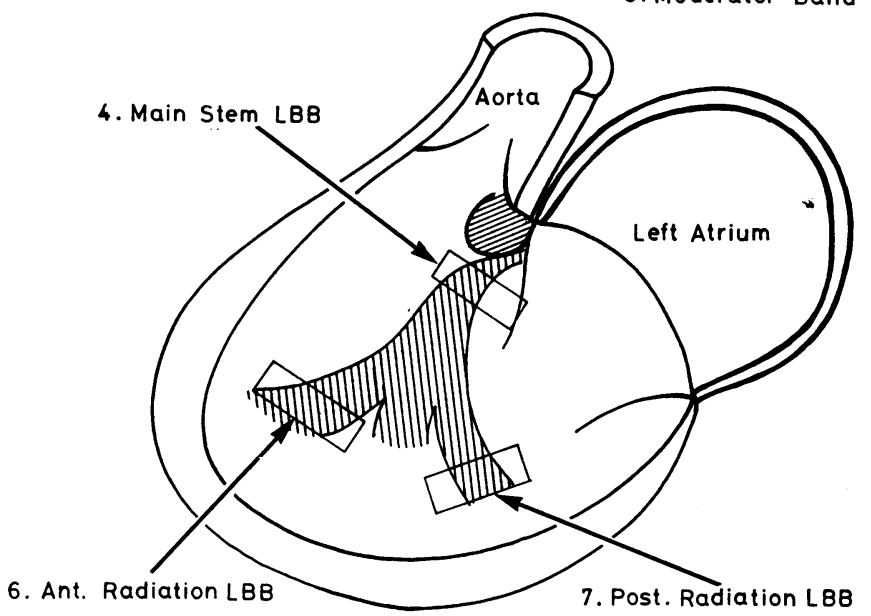

Fig. 1 Drawing of right and left side of heart to indicate sampling sites. (1) Atrioventricular node; (2) penetrating atrioventricular (His) bundle; (3) intranyocardial segment of right bundle-branch; (4) proximal part (main stem) of left bundle-branch; (5) distal part of right bundle-branch; (6 and 7) anterior and posterior radiations of left bundle-branch, respectively. retain their similarity to the working myocardial cells.

\section{(B) ABNORMAL CYTOLOGICAL CHANGES OBSERVED IN CONDUCTING TISSUES}

Conducting tissues were identified in all blocks taken from the atrioventricular node, His bundle, and proximal parts of the bundle-branches, though in some instances examination of further blocks of adjacent tissues was necessary for confirmation. This was particularly necessary with the block taken to show the intramyocardial course of the right bundle-branch (see Subjects and Methods section). The blocks taken to show the distal segments of the left bundle-branches, and to a lesser extent of the right bundle, posed a special problem. These were in most cases either directly involved in the process of myocardial infarction, there being massive infiltration by polymorphonuclear leucocytes, or else they were in an area destroyed by endomyocardial tears with haemorrhage and mural thrombosis. Since we were confident that these blocks were taken from appropriate sites and must include peripheral bundle-branch fibres, we concluded that the conducting tissues were irreversibly damaged by the infarction. When the bundle-branches were positively identified, one or other of the following light microscopical features was always observed.

(1) The conducting tissues could be normal in appearance, being surrounded by or adjacent to normal working myocardium. (2) The conducting tissues could be surrounded by, or be in close approximation to, infarcted working myocardium, though the cells of the conducting tissues themselves had a normal or near normal appearance. 

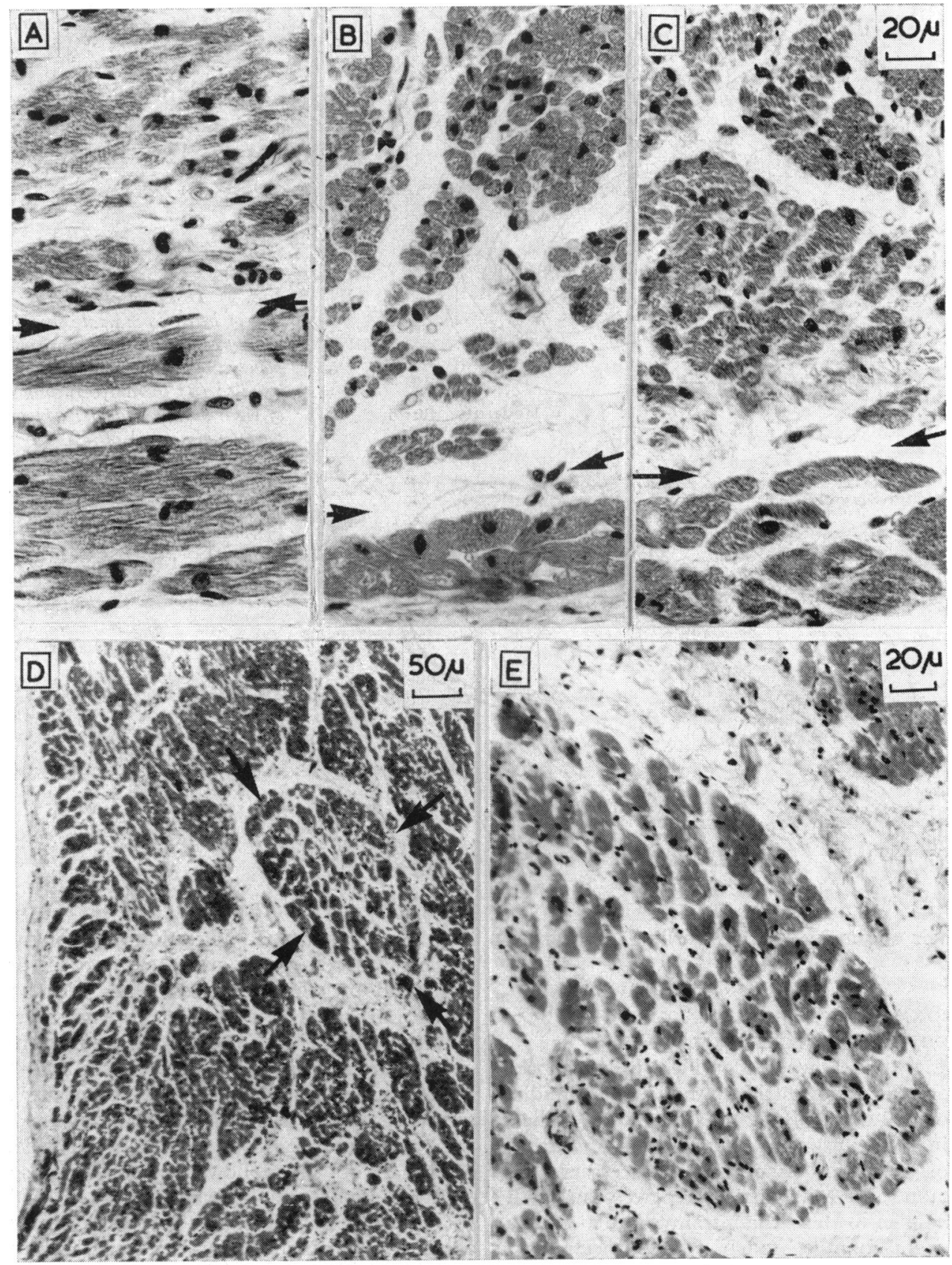

Fig. 2 Normal histology of right and left bundle-branches. Arrows indicate the separation between conduction fibres and working myocardium. (A) Proximal segment of main left bundle-branch. ( $B$ and $C$ ) Fibres of anterior and posterior radiations, respectively. The fibres of the left bundle-branches are slightly larger than those of the working myocardium. ( $D$ and E) Right bundle-branch in its intramyocardial course. The constituent cells are similar in size ¿o working myocardial cells. 

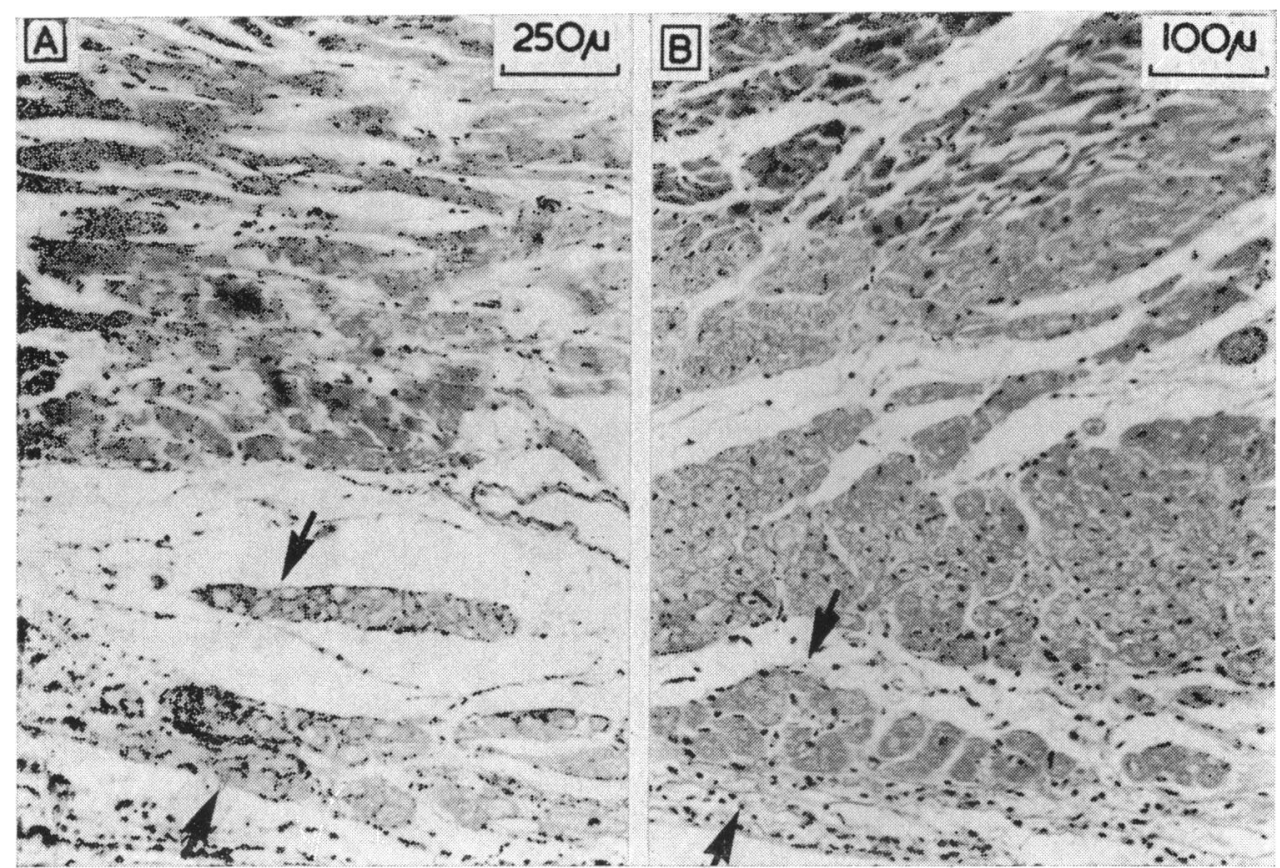

Fig. 3 Histology of left bundle-branches (indicated by arrows), themselves of near normal appearance, though directly adjacent to infarcted myocardium. The supporting tissues are very oedematous. (A) In addition to interstitial oedema some of the conduction fibres show a slight hydropic change. (B) Slight infiltration by polymorphonuclear leucocytes between conduction fibres. The subendocardial layer of working myocardium, bordering the zone of actual necrosis, shows conspicuous hydropic cell swelling.
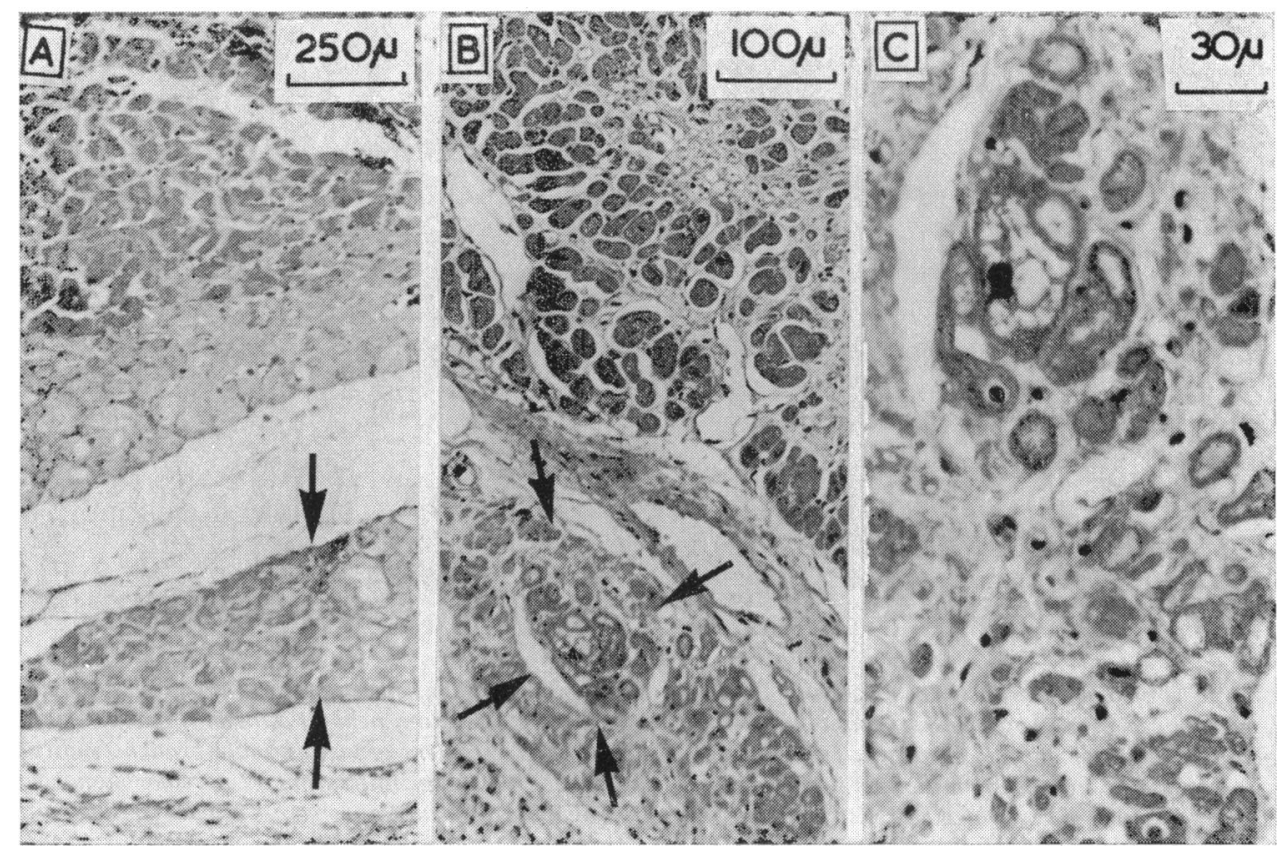

Fig. 4 Hydropic swelling of conduction fibres. (A) Left bundle-branch, showing a minor degree of hydropic cell swelling and interstitial oedema. The adjacent subendocardial layer of myocardium shows similar changes. (B) Right bundle-branch in its intramyocardial course, surrounded by necrotic myocardium and showing severe hydropic changes. (C) Higher magnification of part of right bundle-branch illustrated in $(B)$. The changes are so profound that they suggest actual degeneration of conduction fibres. 


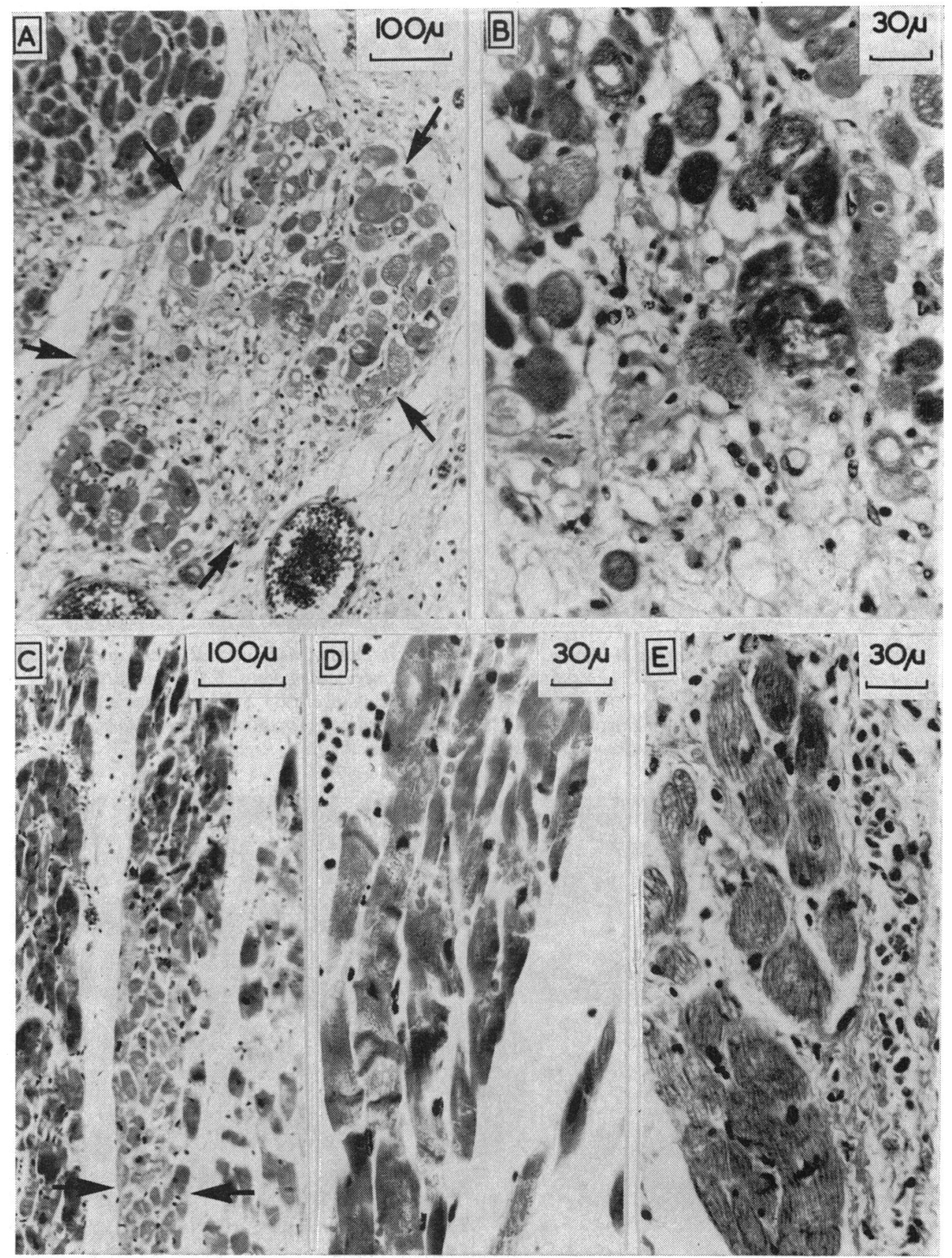

Fig. 5 Necrosis of bundle-branch cells. ( $A$ and $B$ ) Right bundle-branch in its intramyocardial course (indicated by arrows), surrounded by necrotic myocardium. Individual cells show degeneration, next to cells with overt eosinophilia suggestive of actual cell death. (C and D) Intramyocardial segment of right bundle-branch (indicated by arrows), showing patchy distribution of necrotic cells, accompanied by slight infiltration by polymorphonuclear leucocytes. The necrotic bundle-branch cells show conspicuous eosinophilia and irregular cross bands, similar to the changes occurring in working myocardial cells. (E) Left bundle-branch cells, showing patchy eosinophilia, with adjoining cells showing mild hydropic swelling. There is slight infiltration by polymorphonuclear leucocytes. 
However, in these circumstances the interstitial tissues were distinctly oedematous with slight infiltration by polymorphonuclear lecuocytes in some instances (Fig. 3). Such leucocytic infiltration was seen particularly in sections where the left bundlebranches were directly adjacent to infarcted myocardium. (3) There could be conspicuous swelling of the cells of the conducting tissues, accentuating the original cellular structure. In such instances, the cells showed extensive hydropic changes in their core. In some cases these were so profound as to suggest actual hydropic cell degeneration. They were only observed when the conducting tissues were in close contact with infarcted myocardium (Fig. 4). (4) True necrosis of bundle-branch cells could occur, characterised by nuclear pyknosis and karyorrhexis and overt eosinophilia of the cytoplasm with clumping of myofibrillar material (Fig. 5). Alternatively, conducting tissue necrosis was presumed when bundle-branch cells could no longer be positively identified in an area of massive necrosis.

In all instances in which the conducting tissues were abnormal, these changes ( 2 to 4 ) have been interpreted as an expression of ischaemia of the tissues.

\section{(C) FINDINGS IN CASES WITHOUT}

\section{ELECTROCARDIOGRAPHIC EVIDENCE OF} BUNDLE-BRANCH BLOCK (Table 2)

There were 15 cases in this category. None of the 15 hearts had signs of ischaemia of the proximal right bundle-branch, but in 2 of the 15 cases there were ischaemic changes in the proximal left bundle-branch. In these 2 cases, these consisted of swelling of cells, there being no definite signs of

Table 2 Histopathology of bundle-branches in cases without electrocardiographic evidence of bundle-branch block

\begin{tabular}{rlllll}
\hline $\begin{array}{l}\text { Case } \\
\text { No. }\end{array}$ & $\begin{array}{l}\text { PBB } \\
\text { RBimal }\end{array}$ & LBB & $\begin{array}{l}\text { Moderator } \\
\text { band }\end{array}$ & $\begin{array}{l}\text { Distal } \\
\text { L.ant. rad. }\end{array}$ & L. post. rad. \\
\hline 1 & - & - & - & - & - \\
2 & - & - & - & + & - \\
3 & - & - & + & - & - \\
4 & - & - & + & + & + \\
5 & - & - & - & + & + \\
6 & - & - & + & - & - \\
7 & - & - & - & - & + \\
8 & - & - & + & - & + \\
9 & - & - & - & + & + \\
10 & - & - & + & + & + \\
11 & - & - & + & - & + \\
12 & - & - & + & + & + \\
13 & - & - & + & + & - \\
14 & - & + & - & - & + \\
15 & - & + & - & + & + \\
\hline
\end{tabular}

Abbreviations: + , ischaemic change; - , no change; $L$. ant. rad., left anterior radiation; LBB, left bundle-branch; L. post. rad., left posterior radiation; $\mathrm{RBB}$, right bundle-branch. cell necrosis. In both instances the anteroseptal infarction had extended high in the ventricular septum, coming close to the proximal part of the left bundle where it fans out from the main axis. In each of the remaining 13 hearts, there was extensive infarction, but in each instance the infarction was remote from the proximal part of the atrioventricular conduction system.

The peripheral parts of the right and left bundlebranches were more frequently involved as might be expected. In 8 of the 15 cases, there were ischaemic changes in the moderator band, whereas the anterior and posterior fascicles of the left bundle-branch were each involved in 7 cases, showing actual necrosis at the site of infarction.

\section{(D) FINDINGS IN CASES WITH}

\section{ELECTROCARDIOGRAPHIC EVIDENCE OF}

RIGHT BUNDLE-BRANCH BLOCK (Table 3)

There were 9 patients in this category. In 1 patient the bundle-branch block had been transient. Right bundle-branch ischaemia was seen in 8 of the 9 hearts. In the other case the bundle was in close proximity to myocardial necrosis but there was no appreciable oedema of the conducting tissues in the sections that were examined. In this case there were also no ischaemic changes in the proximal part of the left bundle-branch; only the distal parts of both right and left bundle-branches showed definite ischaemic changes; this case was not the one with transient block. One of the 9 cases had right bundle-branch involvement and ischaemic changes of the proximal left bundle; indeed, in this particular case there were ischaemic changes in all segments of the ventricular conducting system. All hearts that showed right bundle-branch involvement had large infarctions that extended high in the ventricular septum, in most instances completely enveloping the right bundle-branch in its intramyocardial course.

Ischaemic changes were seen in the distal parts of the right and left bundle-branches in 7 of the

Table 3 Histopathology of bundle-branches in cases with electrocardiographic evidence of right bundle-branch block

\begin{tabular}{llllll}
\hline $\begin{array}{l}\text { Case } \\
\text { No. }\end{array}$ & $\begin{array}{l}\text { Proximal } \\
\text { RBB }\end{array}$ & LBB & $\begin{array}{l}\text { Moderator } \\
\text { band }\end{array}$ & $\begin{array}{l}\text { Distal } \\
\text { L.ant. rad. }\end{array}$ & L. post. rad. \\
\hline $\mathbf{1}$ & - & - & + & + & + \\
2 & + & - & - & - & - \\
3 & + & - & - & - & - \\
4 & + & - & + & + & + \\
5 & + & - & + & + & + \\
6 & + & - & - & + & + \\
7 & + & - & + & + & + \\
8 & + & + & + & + & + \\
9 & + & - & + & - & - \\
\hline
\end{tabular}

Abbreviations: as in Table 2. 
9 hearts. In 5 of these, all sections (i.e. moderator band and anterior and posterior radiations of the left bundle) showed ischaemia and necrosis at the site of infarction.

\section{(E) FINDINGS IN CASES WITH} ELECTROCARDIOGRAPHIC EVIDENCE OF RIGHT BUNDLE-BRANCH AND LEFT

POSTERIOR HEMIBLOCK (Table 4)

There were 4 patients in this category. Each had right bundle-branch involvement, and 2 of the 4 also showed ischaemic changes in the proximal left bundle-branch. Involvement of the distal parts of the bundle-branches was present in all cases except 1 , in which the moderator band was normal. All 4 hearts showed very extensive infarction encroaching upon the crest of the ventricular septum, completely engulfing the proximal right bundlebranch. Moreover, in each of these cases the right bundle-branch showed patchy cell necrosis as well as cell swelling.

Table 4 Histopathology of bundle-branches in cases with electrocardiographic evidence of right bundle-branch block with left posterior hemiblock

\begin{tabular}{llllll}
\hline $\begin{array}{l}\text { Case } \\
\text { No. }\end{array}$ & $\begin{array}{l}\text { PBoximal } \\
\text { RBB }\end{array}$ & LBB & $\begin{array}{l}\text { Moderator } \\
\text { band }\end{array}$ & $\begin{array}{l}\text { Distal } \\
\text { L.ant. rad. }\end{array}$ & L. post. rad. \\
\hline 1 & + & - & + & + & + \\
2 & + & - & - & + & + \\
3 & + & + & + & + & + \\
4 & + & + & + & + & + \\
\hline
\end{tabular}

Abbreviations: as in Table 2.

(F) FINDINGS IN CASES WITH ELECTROCARDIOGRAPHIC EVIDENCE OF

RIGHT BUNDLE-BRANCH BLOCK AND LEFT

ANTERIOR HEMIBLOCK (Table 5)

There were only 2 patients in this category, in 1 of whom bundle-branch block was transient. Both hearts showed right bundle-branch involvement, but only 1 had ischaemic changes in the proximal left bundle-branch. Neither had involvement of the posterior fascicle of the left bundle-branch; the myocardial infarction was less extensive in this group and did not reach far enough back to affect the posterior fascicle. In each case, however, the moderator band and the anterior division of the left bundle were involved.

\section{(G) FINDINGS IN CASES WITH}

\section{ELECTROCARDIOGRAPHIC EVIDENCE OF} COMPLETE HEART BLOCK (Table 6)

There were 7 cases in this category, in 2 of whom block was transient. In each heart extensive infarction was present, encroaching upon the crest of the ventricular septum. As expected from this observa-
Table 5 Histopathology of bundle-branches in cases with electrocardiographic evidence of right bundle-branch block with left anterior hemiblock

\begin{tabular}{llllll}
\hline $\begin{array}{l}\text { Case } \\
\text { No. }\end{array}$ & RBB & LBB & $\begin{array}{l}\text { Moderator } \\
\text { band }\end{array}$ & $\begin{array}{l}\text { Distal } \\
\text { L.ant. rad. }\end{array}$ & L.post. rad. \\
\hline 1 & + & - & + & + & - \\
2 & + & + & + & + & - \\
\hline
\end{tabular}

Abbreviations: as in Table 2.

Table 6 Histopathology of bundle-branches in cases with electrocardiographic evidence of complete heart block

\begin{tabular}{|c|c|c|c|c|c|}
\hline $\begin{array}{l}\text { Case } \\
\text { No. }\end{array}$ & $\begin{array}{l}\text { Proximal } \\
R B B\end{array}$ & $L B B$ & $\begin{array}{l}\text { Moderator } \\
\text { band }\end{array}$ & $\begin{array}{l}\text { Distal } \\
\text { L. ant. rad. }\end{array}$ & L. post. rad. \\
\hline $\begin{array}{l}1 \\
2 \\
3 \\
4 \\
5 \\
6 \\
7\end{array}$ & $\begin{array}{l}+ \\
+ \\
+ \\
+ \\
+ \\
+ \\
+\end{array}$ & $\begin{array}{l}+ \\
+ \\
+ \\
+ \\
+ \\
+ \\
+\end{array}$ & $\begin{array}{l}+ \\
+ \\
+ \\
- \\
- \\
+ \\
+\end{array}$ & $\begin{array}{l}+ \\
+ \\
+ \\
+ \\
+ \\
+ \\
+\end{array}$ & $\begin{array}{l}+ \\
+ \\
+ \\
- \\
- \\
+ \\
+\end{array}$ \\
\hline
\end{tabular}

Abbreviations: as in Table 2.

tion, there was involvement of the proximal bundlebranches in all instances. Moreover, the conducting tissues, particularly in the right bundle-branch, showed signs of patchy cell necrosis, though the greater part of the bundle showed only cell swelling. The peripheral segments of the bundle-branches were frequently involved, showing necrosis in many instances where the conducting tissues were in contact with infarcted myocardium.

\section{Discussion}

Before discussing the findings, some aspects of the methodology need to be scrutinised. Firstly, the histopathological examination was conducted without prior knowledge of the electrocardiographic findings. Later, it became evident that 15 patients in this series had not developed bundle-branch block. They therefore served as 'controls' with respect to the findings in the remaining 22 patients, all of whom developed electrocardiographic evidence of bundle-branch block.

Secondly, this study was not based on examination of serial sections of the complete atrioventricular conducting system but of sections from selected tissue blocks (Fig. 1). A potential source of misinterpretation is thereby introduced. However, the blocks were always taken at the appropriate sites and the proximal conducting tissues were always positively identified. Moreover, special care was taken to examine the proximal bundle-branches when there was a lack of correlation in cases with infarcted myocardium but without changes in the 
conducting tissues. In such instances adjacent blocks were processed to rule out the possibility of error. It had been assumed, on the other hand, that absence of myocardial infarction in the initial block, in the presence of positively identified conducting tissues, could only mean that the proximal bundlebranches were remote from the zone of infarction. In all such occasions the histological conclusion merely confirmed the impression already obtained from gross inspection. We, therefore, feel that the method employed should yield a reliable picture of the conducting tissues.

In view of these considerations it is worth noting that the 15 patients who had not developed bundlebranch block (the 'controls') did not show histopathological changes in their conducting tissues, whereas most of the 22 patients with bundle-branch block did show such changes. In most instances these changes were found at the sites expected from the electrocardiograms. The change most frequently observed was hydropic swelling rather than actual necrosis of cells. This was interpreted as denoting ischaemia, in the same way that similar changes may occur in ischaemic working myocardium.

It is pertinent to review our own findings in the light of the divergent results obtained by previous investigators. Blondeau and associates (1961) had emphasised that the anatomical substrate for atrioventricular block in anteroseptal infarction was to be found in the bundle-branches rather than in the atrioventricular node or penetrating bundle. This observation has since been supported by the work of several other investigators (Lev et al., 1961; Sutton and Davies, 1968; Hackel and Estes, 1971; Hackel et al., 1972; Hunt et al., 1973) as well as by our present observations. Blondeau et al. (1961, 1967) had also pointed out that there was a positive correlation between bundle-branch involvement and the degree of septal extension of the infarction. In their experience complete necrosis of the right bundle-branch was seen only when the bundle was completely enveloped by the process of infarction: In most instances they observed only partial necrosis. They expressed the view that these observations could explain their clinical experience of transient block occurring during the course of an acute infarction. More recently, the observations of Hackel and associates $(1971,1972)$ have provided support for the views of Blondeau et al. (1961, 1967). They also showed that appreciable necrosis of bundle-branches was an infrequent finding. Twelve out of a total number of 20 hearts, with both anterior and posterior infarctions, had no recognisable lesions in the conducting tissues, whereas the remaining 8 cases with lesions showed only focal necrosis. However, in contrast to these findings other workers have found that massive necrosis of the bundle-branches was the underlying histopathological condition in patients with an acute anteroseptal infarction who developed an atrioventricular conduction disturbance (Sutton and Davies, 1968; Hunt et al., 1973).

Our observations support those of Hackel et al. (1972). We also were unable to detect complete necrosis of bundle-branches in our patients. We suggest, therefore, that the occurrence of a conduction disturbance during the course of an acute anteroseptal myocardial infarction cannot be fully explained on the basis of necrosis of the bundlebranches. Since necrosis was not held to be responsible, Hackel et al. (1972) speculated on alternative mechanisms. Several possibilities were suggested, such as potassium efflux from the infarcted area affecting still viable conduction cells, the cells themselves being affected by minor and potentially reversible degrees of ischaemia, or the effects of lytic enzymes liberated by infiltrating polymorphonuclear leucocytes.

We believe that our investigations provide relevant and significant new information. To the best of our knowledge, no one has yet reported histopathological changes other than necrosis. Furthermore, patients with acute anteroseptal infarction without atrioventricular conduction disturbance have never been studied. The histological appearances of the bundle-branches in the group of patients who did not develop a conduction disturbance were significantly different from those in patients with atrioventricular block. The majority of patients who developed a conduction disturbance had hydropic swelling of cells of the proximal bundle-branches. Infiltration with polymorphonuclear leucocytes was less frequently encountered at these sites, and actual necrosis of proximal bundle-branch cells was a rare phenomenon. In the series of 15 patients without conduction disturbance, hydropic cell swelling was observed only twice, all other cases having no demonstrable changes in the proximal bundle-branches. With respect to the distal ramifications of the bundle-branches, no major differences could be recognised between the 2 groups, necrosis being a frequent finding in both the right and left ventricles. We, therefore, suggest that interstitial oedema and hydropic cell swelling of proximal bundle-branches could well be responsible for the functional impairment of conduction in patients with acute anteroseptal infarction. If this is so, it follows that the conduction disturbances should be transient since cell death is not an automatic consequence of hydropic cell swelling. Even when necrosis was encountered, it 
was patchy. In these circumstances, therefore, only some of the conduction fibres would be irreversibly affected. Our findings suggest, therefore, that after acute anteroseptal infarction with conduction disturbance, complete or partial restoration of conduction may be expected, dependent upon the degree of initial damage. They additionally support previous suggestions that the prognosis of acute anteroseptal infarction is related to the extent of infarction (Lie et al., 1974), this being directly responsible for the involvement or non-involvement of the conducting tissues. The relatively benign changes observed in the conducting tissues are in turn in keeping with clinical experience which indicates that in a high percentage of surviving patients block is transient (Blondeau et al., 1961, 1967).

We thank Mr M. J. Klaver for technical assistance. Photomicrography was performed by $\mathrm{Mr}$ R. E. Verhoeven and artwork by Mrs S. Y. Ho.

\section{References}

Becker, A. E., and Anderson, R. H. (1976). Morphology of the human atrioventricular junctional area. In The Conduction System of the Heart. Structure, Function and Clinical Implications, pp. 263-286. Ed. by H. J. J. Wellens, K. I. Lie, and M. J. Janse. H.E. Stenfert Kroese, B.V., Leiden.

Blondeau, M., Maurice, P., Reverdy, V., and Lenègre, J. (1967). Troubles du rhythme et de la conduction auriculoventriculaire dans l'infarctus du myocarde récent. Considérations anatomiques. Archives des Maladies du Coeur, 60, 1733-1751.
Blondeau, M., Rizzon, P., and Lenègre, J. (1961). Les troubles de la conduction auriculo-ventriculaire dans l'infarctus myocardique récent. II. Etude anatomique. Archives des Maladies du Coeur, 53, 1104-1117.

Davies, M. J. (1971). Pathology of Conducting Tissue of the Heart, p. 129. Butterworth, London.

Hackel, D. B., and Estes, E. H., Jr. (1971). Pathologic features of atrioventricular and intraventricular conduction disturbances in acute myocardial infarction. Circulation, 43, 977-979.

Hackel, D. B., Wagner, G., Ratliff, N. B., Cies, A. B., and Estes, E. H. (1972). Anatomic studies of the cardiac conducting system in acute myocardial infarction. American Heart fournal, 83, 77-81.

Hunt, D., Lie, J. T., Vohra, J., and Sloman, G. (1973). Histopathology of heart block complicating acute myocardial infarction. Correlation with the His bundle electrogram. Circulation, 48, 1252-1261.

Lev, M., Unger, P. N., Lesser, M. E., and Pick, A. (1961). Pathology of the conduction system in acquired heart disease. Complete right bundle branch block. American Heart fournal, 61, 593-614.

Lie, K. I., Wellens, H. J. J., Schuilenburg, R. M., Becker, A. E., and Durrer, D. (1974). Factors influencing prognosis of bundle branch block complicating acute anteroseptal infarction. Circulation, 50, 935-941.

Norris, R. M., Mercer, C. J., and Croxson, M. S. (1972). Conduction disturbances due to anteroseptal myocardial infarction and their treatment by endocardial pacing. American Heart fournal, 84, 560-566.

Sutton, R., and Davies, M. (1968). The conduction system in acute myocardial infarction complicated by heart block. Circulation, 38, 987-992.

Requests for reprints to Dr A. E. Becker, Department of Pathology, Wilhelmina Gasthuis, Eerste Helmersstraat 104, Amsterdam, The Netherlands. 